\title{
Exogenous gibberellic acid application influences on vegetative and reproductive aspects in gladiolus
}

\author{
Abdur Rahman ${ }^{1}$, Ibrar Hussain²*, Ghulam Nabi ${ }^{1}$, Ziaullah $^{2}$
}

\begin{abstract}
Ornamental plants like gladiolus are suitable option for growers with lower amount of land, as they are highly economic and have lower cost of production. An experiment was conducted with aim to study the exogenous application influence of gibberellic acid on vegetative and reproductive characteristics of gladiolus was conducted under the subtropical conditions. The experiment was laid out in two factors randomized complete block design and replicated three times. Gibberellic acid $\left(\mathrm{GA}_{3}\right)$ was used in different concentrations $\left(0,50,100,150,200 \mathrm{mg} \mathrm{L}^{-1}\right)$ to corms of two cultivars of gladiolus ('White Prosperity' and 'Red Advance'). Results showed that most of the parameters were significantly influenced by gibberellic acid at $200 \mathrm{mg} \mathrm{L}^{-1}$. The maximum sprouting, number of leaves plant ${ }^{-1}$, daughter corms per plant, less number of days to corm sprouting, days to spike emergence and flower opening were recorded in plants treated with $200 \mathrm{mg} \mathrm{L}^{-1}$ gibberellic acid $\left(\mathrm{GA}_{3}\right)$. 'Red Advance' produced more number of leaves plant ${ }^{-1}$, corm diameter, corm weight, and less number of days to spike emergence and flower opening. It can be concluded from the present findings that the treatment of corms with $200 \mathrm{mg} \mathrm{L}^{-1}$ gibberellic acid can improve the growth and yield of cultivar Red Advance than White prosperity under the subtropical conditions.
\end{abstract}

Keywords: Gladiolus grandiflorus, plant hormones, corms, vegetative growth.

\section{Resumo}

A aplicação exógena de ácido giberélico influencia os aspectos vegetativos e reprodutivos do gladíolo

Plantas ornamentais, como gladíolos, são uma boa opção para produtores com área limitada, pois são altamente rentáveis e possuem menor custo de produção. O experimento foi conduzido com o objetivo de estudar a influência da aplicação exógena do ácido giberélico nas características vegetativas e reprodutivas de gladíolos, em condições subtropicais. O delineamento experimental foi em blocos casualizados com dois fatores: cultivares (White Prosperity e Red Advance) e ácido giberélico (GA $)(0,50,100,150$, $200 \mathrm{mg} \mathrm{L}^{-1}$ ), com três repetições. Os resultados mostram que a maioria dos parâmetros foi significativamente influenciada pelo ácido giberélico. Maior porcentagem de brotação, número de folhas e cormos planta ${ }^{-1}$, bem como menor número de dias para brotação, surgimento da espiga e abertura floral foram registrados nas plantas tratadas com $200 \mathrm{mg} \mathrm{L}^{-1}$ de ácido giberélico (GA $)$. A cultivar Red Advance, além de menor número de dias para surgimento da espiga e a abertura da flor, apresentou maior número de folhas por planta e maior diâmetro e peso dos cormos. Conclui-se, com base nos resultados, que o tratamento de cormos com $200 \mathrm{mg} \mathrm{L}^{-1}$ de ácido giberélico pode incrementar mais o crescimento e o rendimento da cultivar de gladíolo Red Advance do que da White Prosperity nas condições de região subtropical.

Palavras-chave: Gladiolus grandiflorus, hormônios vegetais, cormos, crescimento vegetativo.

\section{Introduction}

Gladiolus (Gladiolus grandiflorus) also known as "Sword Lily" is an ornamental, monocot, flowering bulbous plant of family Irideaceae having one hundred and fifty known species (Negi et al., 1982). Gladiolus has herbaceous stem and narrowly linear leaves, sheathing at the base with flattened sides (Negi et al., 2014). Gladiolus flower can be found in various colours, with floret shape of round, triangular, flattened, orchid like and petal may be planed, ruffled, lacinitated, bent or deeply folded (Wilfret, 1980).

It is commonly used in landscape, beds and gardens as cut flower and frequently used in bouquets, in floral

\footnotetext{
${ }^{1}$ The University of Agriculture Peshawar, Department of Horticulture, Peshawar, Pakistan.

${ }^{2}$ Horticulture section, Agricultural Research Institute Tarnab, Peshawar, Pakistan.

"Corresponding author: ibrar_horti@yahoo.com and hussain0334@uel.br
}

Received Oct 03, 2019 | Accepted May 07, 2020| Available online May 20, 2020

Licensed by CC BY 4.0

https://doi.org/10.1590/2447-536X.v26i2.2100

Area Editor: Ana Maria Mapeli 
arrangements and garland (Halder et al., 2007). Gladiolus is famous for the name as queen of bulbous flowers owing to its flower spikes with pleasant florets of attractive shapes, massive form, and excellent shelf life.

The potential use of growth regulators in flower production has created considerable scientific interest in recent years. Many studies have revealed that applying growth regulators can affect the growth of gladiolus (Jinesh et al., 2011). Plant growth regulators play an important role in enhancing the floriculture industry. Plant growth regulators are involved in improving the growth, yield and quality of flower. Growth regulators are found effective in controlling growth and flowering in gladiolus (Ahmad et al., 2002). Growth and development are to be regulated either by a single or by interaction of several hormones. They play major role in directing the movement of organic metabolites and in establishing the sink (Nuvale et al., 2010).

Among growth regulators, gibberellic acid are well known for stimulating corm sprouting, plant height, leaves elongation, induction of flowering, corms weight of bulbous plants at different concentrations (Olszewski et al., 2002; Lee and Rhee, 2005; Vijai et al., 2007).

In developing countries where the focus of growers are cereal crops, the demand for this ornamental crop got the attention of growers due to the color variation of its florets and considerable commercial potential for local as well as export market. A number of factors such as planting depth, timing, fertilizer dose, etc, and use of growth regulators (GA ${ }_{3}$ and IAA) can enhance the quality and production of gladiolus flowers and corm yield (Uddin et al., 2002, Hussain and Amin, 2018).

The objectives of this study were to investigate the response of two gladiolus cultivars to gibberellic acid treatments and to determine the effects of exogenous application of gibberellic acid on vegetative and reproductive characteristics of gladiolus.

\section{Materials and Methods}

The experiment was conducted during at Horticulture farm, Agriculture Research Institute Tarnab, Peshawar, Pakistan. The experiment was laid out in randomized complete block design with two factors. During the experiment the corms of gladiolus cultivars 'White Prosperity' and 'Red Advance' imported from Holland were treated with five different concentration of gibberellic acid $\left(0,50,100,150\right.$ and $\left.200 \mathrm{mg} \mathrm{L}^{-1}\right)$ and was replicated three times. A total of 24 corms were used per treatment. The gibberellic acid solution was prepared by dissolving 50, 100, 150, and $200 \mathrm{mg} \mathrm{GA}$ in 1 liter of water. Gibberellic acid was first dissolved in $50 \%$ ethanol solution, and then volume was raised to 1 liter. Corms were soaked for 24 hours in gibberellic acid solutions before sowing in field.

The experimental field was ploughed thoroughly and well decomposed farm yard manure was incorporated during plot preparation to increase the fertility. The disease free and healthy corms of same size of both cultivars were sown on $30^{\text {th }}$ March, 2016 at the plant spacing of $15 \mathrm{~cm}$ and row to row spacing of $75 \mathrm{~cm}$. All corms were sown at a depth of $6 \mathrm{~cm}$. Total experimental plot size was $27 \mathrm{~m}^{2}$. Hand weeding was practiced in the field. Irrigation was done on weekly basis.

Before planting of corms, soil samples were collected from the field, analyzed showing the nitrogen (0.025 mg $\mathrm{Kg}^{-1}$ ), phosphorus (4.2 $\mathrm{mg} \mathrm{Kg}^{-1}$ ), potassium (80 $\left.\mathrm{mg} \mathrm{Kg}^{-1}\right)$, organic matter $(0.51 \%)$, soil $\mathrm{pH}(8.0)$ and electrical conductivity $\left(0.20 \mathrm{dsm}^{-1}\right)$. During the experiment the following variables were studied, days to corms sprouting (number of days for corms sprouting was counted from the date of corms sowing to the date of corms sprouting; corms sprouting percentage; number of leaves plant $^{-1}$; days to spike emergence (number of days for spike emergence was counted from the date of corm sowing to the first spike emergence); days to flower opening, diameter of daughter corms (cm); corms weight $(\mathrm{g})$; number of daughter corms plant $^{-1}$. The data collected on various parameters were analyzed by using Statistical computer software "Statistix 8.1" for computing both ANOVA and LSD at 5\% level of probability (Jan et al., 2009).

\section{Results and Discussion}

\section{Days to corms sprouting}

The analysis of variance showed that the various gibberellic acid concentrations had significant effect on days to corm sprouting of gladiolus. While cultivars and their interaction showed non-significant results (Table 1).

The highest days to corm sprouting was observed in control treatment, while minimum number days to corms sprouting observed in plants treated with $200 \mathrm{mg} \mathrm{L}^{-1}$ gibberellic acid $\left(\mathrm{GA}_{3}\right)$. It might be due to the high nutrients preserved and gibberellic acid which can enhance the cell expansion and promotes synthesis of DNA in cells (Jinesh et al., 2011).

\section{Corms sprouting percentage}

Gibberellic acid concentrations having significant effect on sprouting percentage of gladiolus. The cultivars and interaction had no significant results. Sprouting percentage of $96.3 \%$ was recorded in plants treated with $200 \mathrm{mg}$ $\mathrm{L}^{-1}$ gibberellic acid, followed by $91.7 \%$ with $150 \mathrm{mg} \mathrm{L}^{-1}$ gibberellic acid treatment, while less sprouting $71.8 \%$ percentage were noted in control treatment (Table 1). 
Table 1. Effects of different gibberillic acid $\left(\mathrm{GA}_{3}\right)$ levels on days to corm sprouting, sprouting percentage, leaves per plant and spike emergence of different gladiolus cultivars

\begin{tabular}{|c|c|c|c|c|}
\hline Cultivar & $\begin{array}{c}\text { Corm } \\
\text { sprouting (Days) }\end{array}$ & $\begin{array}{c}\text { Corm } \\
\text { sprouting }(\%)\end{array}$ & $\begin{array}{c}\text { Leaves } \\
\text { per plant }\end{array}$ & $\begin{array}{c}\text { Spike } \\
\text { emergence } \\
\text { (Days) }\end{array}$ \\
\hline White Prosperity & 20.2 & 84.1 & $8.4 \mathrm{~b}$ & $55.3 \mathrm{a}$ \\
\hline Red Advance & 20.4 & 84.3 & $9.8 \mathrm{a}$ & $53.8 \mathrm{~b}$ \\
\hline $\mathbf{F}$ & 0.16 & 0.02 & 6.23 & 32.43 \\
\hline \multicolumn{5}{|l|}{ Gibberellic acid } \\
\hline $\mathbf{0}$ & $22.8 \mathrm{a}$ & $71.8 \mathrm{~d}$ & $7.6 \mathrm{~b}$ & $60.5 \mathrm{a}$ \\
\hline 50 & $21.5 \mathrm{ab}$ & $77.2 \mathrm{~cd}$ & $8.1 \mathrm{~b}$ & $57.0 \mathrm{~b}$ \\
\hline 100 & $20.1 b c$ & $85.4 b c$ & $9.0 \mathrm{ab}$ & $54.3 \mathrm{c}$ \\
\hline 150 & $18.8 \mathrm{~cd}$ & $91.7 \mathrm{ab}$ & $10.2 \mathrm{a}$ & $52.2 \mathrm{~d}$ \\
\hline 200 & $17.9 \mathrm{~d}$ & $96.3 \mathrm{a}$ & $10.6 \mathrm{a}$ & $60.5 \mathrm{a}$ \\
\hline $\mathbf{F}$ & 11.86 & 11.89 & 4.46 & 215.98 \\
\hline \multicolumn{5}{|l|}{ CxG } \\
\hline $\mathbf{F}$ & 0.15 & 2.03 & 0.87 & 1.07 \\
\hline CV\% & 6.89 & 8.67 & 16.16 & 1.36 \\
\hline
\end{tabular}

Means followed by the different letter are significantly different at $5 \%$ level of significance by LSD test. ns $=$ non significant and $*=$ Significant at $5 \%$ level of significance.

The balance between growth promoters hormones and growth retardant hormones can play an important role in plant growth and development. As abscisic acid is dominant and hence responsible for the dormancy in gladiolus corms. The freshly harvested corms of gladiolus having dormancy for the period of three months. Reduction in the level of $\mathrm{ABA}$ is the major factor causing endogenous hormonal balance, which promotes the sprouting percentage in gladiolus corms. Gladiolus corms treated with $150 \mathrm{mg} \mathrm{L}^{-1}$ and $200 \mathrm{mg} \mathrm{L}^{-1}$ gibberellic acid concentrations resulted in highest sprouting percentage (Table 1). Which shows that, $150 \mathrm{mg} \mathrm{L}^{-1}$ and $200 \mathrm{mg} \mathrm{L}^{-1}$ gibberellic acid applications was actively involved in the breaking of reserved food material with the help of hydrolytic enzymes present in $\mathrm{GA}_{3}$ (Padmalatha et al., 2013).

\section{Number of leaves per plant}

The mean value of different cultivars of gladiolus studied showed that number of leaves per plant produced by Red Advance (9.8) were higher than White Prosperity (8.4). Data recorded for gibberellic acid treatment (Table 1), reveal that maximum number of leaves per plant (10.6) were produced in plants treated with $200 \mathrm{mg} \mathrm{L}^{-1}$, followed by plants treated with $150 \mathrm{mg} \mathrm{L}^{-1}$ gibberellic acid, while the minimum numbers (7.6) of were recorded in control treatment.

Various factors play part to enhance the growth of gladiolus plants, like the genetical makeup of cultivars, favorable environmental conditions and soil texture. Hence more number of leaves plant ${ }^{-1}$ in Red Advance may be due to its genetic characteristics that best suits to soil and climatic condition provided (Al-Humaid, 2004). An increase in growth parameter like number of leaves, with the application of $\mathrm{GA}_{3}$ might be the enhanced cell division occurred in shoot tip with cell elongation and growth promoter action of gibberellic acid (Sudhakar and Kumar, 2012). In various studies, gibberellin application exogenously found as a promoter of shoot elongation and vegetative growth (Xu et al, 1997; Chopde et al., 2015).

\section{Days to spike emergence}

Days to spike emergence (Table 1) for both cultivars studied showed that cultivar Red Advance took less days (53.8) than White Prosperity (55.3). The mean value of different gibberellic acid concentrations proved that less number of days to spike emergence (48.8) was noticed in plants with the application of $200 \mathrm{mg} \mathrm{L}^{-1} \mathrm{GA}_{3}$ treatment, while more number (60.5) days were taken 
by plants in control treatment. Less number of days to spike emergence in Red Advance cultivar might be due to the presence of more photosynthates. As more number of leaves was produced in Red Advance which served as source of photosynthates synthesis, intern enhanced time for spike emergence (Hussain et al., 2011; Zubair et al., 2006). Minimum days to spike emergence may be due to the stimulating effect of the gibberellic acid (Kumari et al., 2011).

\section{Days to flower opening}

Data pertaining days to flower opening showed that Red Advance took less number of days (74.5) to than White Prosperity (76.1) to flower opening. Different concentrations of gibberellic acid had significant response for days to flower opening. Less number of days (72.7) to flower opening was found in $200 \mathrm{mg} \mathrm{L}^{-1} \mathrm{GA}_{3}$ application, while the more number of days (79.2) to flower opening was recorded in plants with no $\mathrm{GA}_{3}$ application (Table 2).

Table 2. Effects of different gibberillic acid $\left(\mathrm{GA}_{3}\right)$ levels on days to flower opening, corm diameter, corm weight and number of daughter corms of different gladiolus cultivars

\begin{tabular}{|c|c|c|c|c|}
\hline Cultivar & $\begin{array}{c}\text { Flower } \\
\text { opening ( Days) }\end{array}$ & $\begin{array}{c}\text { Corm } \\
\text { diameter }(\mathrm{cm})\end{array}$ & $\begin{array}{c}\text { Corm } \\
\text { weight }(g)\end{array}$ & $\begin{array}{c}\text { Daughter } \\
\text { corms }\end{array}$ \\
\hline White prosperity & $76.1 \mathrm{a}$ & $2.8 \mathrm{~b}$ & $12.0 \mathrm{~b}$ & $2.7 b$ \\
\hline Red Advance & $74.5 \mathrm{~b}$ & $3.1 \mathrm{a}$ & $13.4 \mathrm{a}$ & $3.0 \mathrm{a}$ \\
\hline $\mathbf{F}$ & 73.24 & 4.75 & 21.61 & 6.44 \\
\hline \multicolumn{5}{|l|}{ Gibberellic acid } \\
\hline 0 & $79.2 \mathrm{a}$ & $2.47 \mathrm{C}$ & $10.7 \mathrm{c}$ & $2.4 \mathrm{c}$ \\
\hline 50 & $76.6 b$ & $2.84 \mathrm{~b}$ & $11.5 \mathrm{~b}$ & $2.5 \mathrm{bc}$ \\
\hline 100 & $75.4 \mathrm{c}$ & $2.85 b$ & $11.9 \mathrm{~b}$ & $2.8 \mathrm{~b}$ \\
\hline 150 & $73.9 \mathrm{~d}$ & $3.37 \mathrm{a}$ & $14.9 \mathrm{a}$ & $3.3 \mathrm{a}$ \\
\hline 200 & $72.7 \mathrm{e}$ & $3.25 \mathrm{a}$ & $14.5 \mathrm{a}$ & $3.5 \mathrm{a}$ \\
\hline $\mathbf{F}$ & 77.76 & 16.39 & 33.35 & 17.58 \\
\hline \multicolumn{5}{|l|}{ CxG } \\
\hline $\mathbf{F}$ & 1.62 & 0.21 & 1.25 & 0.80 \\
\hline $\mathrm{CV} \%$ & 0.92 & 7.36 & 6.29 & 10.41 \\
\hline
\end{tabular}

Means followed by the different letter are significantly different at $5 \%$ level of significance by LSD test.

$\mathrm{ns}=$ non significant and $*=$ Significant at $5 \%$ level of significance.

Early flower opening in Red Advance cultivar might be due to the early vegetative growth. As more photosynthates production was found in the plants of Red Advance which enhance the vegetative growth parameters and resulted in the earlier completion of life cycle, hence promoted the reproductive growth as well (Al-Humaid, 2004; Zubair et al., 2006). Application of $\mathrm{GA}_{3}$ has positive impact on regulating vegetative growth and early floral initiation. Gibberellic acid promoted vegetative growth and increased the photosynthetic and metabolic activities caused more transport and utilization of photosynthetic products resulted early flowering in gladiolus (Sharma, 2004; Devadanam et al., 2007; Dogra et al., 2012).

\section{Diameter of corms (cm)}

The observation about diameter of corms $(\mathrm{cm})$ is presented in Table 2, indicates that maximum corm diameter was observed $(3.04 \mathrm{~cm})$ in Red Advance and minimum $(2.87 \mathrm{~cm})$ in White Prosperity. The mean value of different gibberellic acid concentrations revealed that maximum corm diameter was obtained by plants treated with $150 \mathrm{mg} \mathrm{L}^{-1}$ and $200 \mathrm{mg} \mathrm{L}^{-1}$ gibberellic acid, respectively. The favorable 
environmental and soil conditions for development of corms makes cultivar Red advance to develop thick corm than White prosperity. Maximum corm diameter was due to that gibberellic acid helps plants to produce more photosynthates and carbohydrates accumulation, as a result cause large corm size. Gibberellins lead to increased cell division and cell growth apparently which lead to increased elongation of root and it enhances corm diameter (Chopde et al., 2012).

\section{Corm weight (g)}

Gladiolus cultivars and different concentrations of gibberellic acid had significant difference for corm weight. Mean Table 2 illustrated that maximum corm weight (13.39 g) was higher for Red Advance than White Prosperity (12.03 g). Maximum corm weight (14.90 g) was produced by the plants treated with gibberellic acid of $150 \mathrm{mg} \mathrm{L}^{-1}$ and $200 \mathrm{mg} \mathrm{L}^{-1}$. Maximum corm weight were obtained in Red Advance, it might be due to the best adaptation of gladiolus cultivar and more accumulation of photosynthates and carbohydrates production in which it had obtained a good and well developed plants, as a result it promoted the best corm weight (Yousif et al., 2006). More food is reserved by larger size corms which help in growth and development, with the combination of $150 \mathrm{mg}$ $\mathrm{L}^{-1}$ gibberellic acid increases the single corm weight (Bhat et al., 2009; Hossian, 2011; Amin, 2013).

\section{Number of daughter corms plant ${ }^{-1}$}

Data related to number of daughter corms plant ${ }^{-1}$ (Table 2) indicates that gladiolus cultivars Red Advance had more number of daughter corms than White Prosperity. A significant response was observed regarding gibberellic acid for number of daughter corms plant $^{-1}$ of gladiolus. More number of daughter corms (3.5) plant $^{-1}$ were obtained in plants with the application of $200 \mathrm{mg} \mathrm{L}^{-1}$ gibberellic acid concentration, and less number (2.4) of daughter corms produced plant ${ }^{-1}$ were recorded in control treatment.

Higher number of corms plant ${ }^{-1}$ in Red Advance cultivar, it might be due to the more accumulation of photosynthates production and favorable climatic conditions increase concentrations of $\mathrm{GA}_{3}$ increased the corms number (Khan and Ahmad, 2004; Lahiji, 2013).

\section{Conclusions}

It is concluded from the above results that gladiolus cultivar Red Advance had more positive results as compare to White Prosperity, further the application of gibberellic acid application at higher concentration gave optimum results for vegetative, floral and corm development.

\section{Authors Contribution}

A.R. ${ }^{0000-0002-1784-1995}$ and I.H. ${ }^{0000-0002-5784-7902}$ Conceived and designed the experiments; A.R. and Z. ${ }^{0000-0002-1324-4405}$ : Performed the experiments; G.N. ${ }^{0000-0001-9406-5195}$ and Z.: Contributed reagents/ materials/analysis tools; I.H. and A.R.: Wrote the paper.

\section{Acknowledgements}

The authors thank The University of Agriculture, Peshawar and Agricultural Research Institute, Tarnab, Peshawar, Pakistan for financial support.

\section{References}

AL-HUMAID, A.I. Adaptation of some gladiolus cultivars to Al-Qassim environmental conditions. Arab Gulf Journal of Scientific Research, v.22, p.248-256, 2004.

AMIN, N.U.; KHATTAK, A.M.; AHMAD, I.; ARA, N.; ALAM, A.; ALI, A.; ALI, I. Corm and cormel size of gladiolus greatly influenced growth and development of subsequent corm production. Pakistan Journal of Botany, v.45, n.4, p.1407-1409, 2013.

BHAT, Z.A.; PAUL, T.M.; MIR, M.M. Effect of corm size and planting geometry on growth, flowering and corm production in gladiolus cv. white prosperity. Journal of Ornamental Horticulture, v.12, n.1, p.35-38, 2009. DOI: https://doi.org/10.9734/AJAHR/2018/39465

CHOPDE, N.; PATIL, A.; BHANDE, M.H. Growth, yield and quality of gladiolus as influenced by growth regulators and methods of application. Plant Archives, v.15, n.2, p.691-694, 2015.

CHOPDE, N.; GONGE, V.; DALAL, S. Growth flowering and corm production of gladiolus as influenced by foliar application of growth regulators. Plant Archives, v.12, p.41-46, 2012.

DEVADANAM., A.; SABLE, A.P.B.; SHINDE, B.N.; HALDEWAD, A.M. Effect of foliar spray of plant growth regulators on growth and yield of tuberose (Polianthes tuberose L.). Journal of Maharashtra Agricultural University, v.32, p.282-283, 2007.

DOGRA, S.; PANDEY, R.K.; BHAT, D.J. Influence of gibberellic acid and plant geometry on growth, flowering and corm production in gladiolus (Gladiolus grandiflorus) under Jammu agroclimate. International Journal of Pharma and Bio Sciences, v.3, n.4, p.1083-1090, 2012. 
GOWDA, J.V.N. Effect of gibberellic acid on growth and flowering of rose cv. Super Star. Indian Rose Annuals, v.4, p.185-187, 1985.

HOSSIAN, M.J.; AMIN, M.R.; CHOUDHURY, S.; UDDAIN, J. Effect of corm size and different doses of phosphorous on the growth, corm and cormel development of Gladiolus. Libyan Agriculture Research Center Journal International, v.2, n.1, p.09-14, 2011.

HALDER, N.K.; SIDDIQUI, M.A.; AHMAD, R.; SHARIFUZZAMAN, S.M.; BEGUM, K.A. Effect of boron and zinc fertilization on flower yield and quality of gladiolus in grey terrace soils of Bangladesh. Journal of Soil Nature, v.1, n.3, p.40-45, 2007.

HUSSAIN, I.; AMIN, N.U. Caladium cv. Florida sweetheart production at different planting depths and sowing dates. Ornamental Horticulture, v.24, n.4, p.311-316, 2018. DOI: https://doi.org/10.14295/oh.v24i4.1194

HUSSAIN, I.; KHATTAK, A.M.; AMIN, N.U.; RAHMAN, H.; MUNSIF, F. Response of cormels of different freesia cultivar to various phosphorus levels. Sarhad Journal of Agriculture, v. 27, n.1, p.39-42, 2011.

JINESH, P.; PATEL, H.; CHAVDA, J.; SAIYAD, M. Effect of plant growth regulators on flowering and yield of gladiolus (Gladiolus grandiflorus L.) cv. American Beauty. Asian Journal of Horticulture, v.5, p.483-485, 2010. DOI: https://doi.org/10.5958/2249-880X.2018.00015.4

JINESH, P.M.; PATEL, H.C.; CHAVDA, J.C.; SAIYAD, M.Y. Effect of plant growth regulators on growth and yield of gladiolus cv. American-Beauty. Journal of Agricultural Science, v.7, n.1, p.141-143, 2011.

KHAN, M.A.; AHMAD, I. Growth and flowering of Gladiolus hortulanus L. cv. Winf Song as influences by various levels of NPK. International Journal of Agricultural Biology, v.6, p.1037-1039, 2004.

KUMARI, S.; PATEL, B.S.; MAHAWER, L. N. Influence of gibberellic acid and planting date on growth and flowering in gladiolus cv. Yellow Frilled. Journal of Horticulture Science, v.6, n.2, p.114-117, 2011.

LEE, K.; RHEE, S.R. Development of floral organ and physio-chemical changes of cut Iris Hollandica Blue magic according to plant growth regulators and storage temperature. Acta Horticulturae, v.673, p.315-321, 2005. DOI: https://doi.org/10.17660/ActaHortic.2005.673.40

LAHIJI, M.F. Effect of growth regulators in corm production, growth and development of corm in gladiolus cultivars (Rose supreme, White Prosperity). International Journal of Agronomy and Plant Production, v.4, n.12, p.3186-3191, 2013.
NEGI, S.S.; SHARMA, T.V.R.S.; RAGHAVA, S.P.S.; SHRINIVASAN, V.R. Variability studies in gladiolus. Indian Journal of Horticulture, v.39, p.269-272, 1982.

NEGI, R.; KUMAR, S.; DHIMAN, S.R. Evaluation of different cultivars of gladiolus (Gladiolus grandiflorus L.) suitable for low hills of Himachal Pradesh. Indian Journal of Science of Research and Technology, v.2, n.6, p.6-11, 2014.

NUVALE, M.U.; AKLADE, S.A.; DESAI, J.R.; NANNAVARE, P.V. Influence of PGR's on growth, flowering and yield of chrysanthemum (Dendranthem grandiflora Tzvelev) cv. 'IIHR-6'. International Journal of Pharma and Biosciences, v.1, n.2, p.1-4, 2010.

OLSZEWSKI, N.; SUN, T.P.; GUBLER, F. Gibberellin signaling, biosynthesis, catabolism and response pathways. The Plant Cell, v.1 n.4, p.61-80, 2002. DOI: https://doi. org/10.1105/tpc.010476

PADMALATHA, T.; REDDY, G.S.; CHANDRASEKHAR, R.; SHANKAR, A.S.; CHATURVEDI, A. Effect of preplanting soaking of corms with chemicals and plant growth regulators on dormancy breaking and corm and cormel production in Gladiolus. International Journal of Plant, Animal and Environmental Sciences, v.3, n.1, p.28-33, 2013. DOI: https://doi.org/10.5958/0976058X.2014.00664.7

SHARMA, J.R.; GUPTA, R.B.; PANWAR, R.D. Growth flowering and corm production gladiolus cv. Friendship as influenced by foliar application of nutrients and growth regulators. Journal of Ornamental Horticulture, v.7 n.34, v.154-158, 2004.

SUDHAKAR, M.; KUMAR, S.R. Effect of growth regulators on growth, flowering and corm production of gladiolus (Gladiolus grandiflorus L.) cv. White Friendship. Indian Journal of Plant Sciences, v.1, n.2-3, p.133-136, 2012.

UDDIN, F.M.; RAHMAN, M.M.; RABBANI, M.G.; MANNAN, M.A. Effect of corm size and depth of planting on the growth and flowering of gladiolus. Pakistan Journal of Biological Sciences, v.5, n.5, p.553-555, 2002. DOI: https://doi.org/10.3923/pjbs.2002.553.555

VIJAI, K.U.; SINGH, R.P.; SINGH, A.R. Effect of gibberellic acid and growing media on vegetative and floral attributes of gladiolus. Indian Journal of Horticulture, v.64, p.73-76, 2007.

WILFRET. 1980. Introduction to floriculture, (Larson ed). Academic Press. A subsidiary of Harcourt Brace. Jovanovich, Publishers. pp.607. 
XU, Y.L.; GAGE, D.A.; ZEEVAART, J.A. 1997. Gibberellins and stem growth in Arabidopsis thaliana (Effects of photoperiod on expression of the $\mathrm{GA}_{3}$ and $\mathrm{GA}_{5}$ Loci). Plant physiology, v.114, n.4, p.1471-1476, 1997. DOI: https://doi.org/10.1104/pp.114.4.1471

YOUSIF, S.; MAHMOUD, S.; SAFAR, A. Effect of GA treatment and nitrogen on growth and development of Gladiolus corms. Pakistan Journal of Biological Sciences, v.9, n.13, p.2516-2519, 2006. DOI: https://doi. org/10.3923/pjbs.2006.2516.2519
ZUBAIR, M.; WAZIR, F.K.; AKHTAR, S.; AYUB, G. Planting dates affect floral characteristics of gladiolus under the soil and climatic conditions of Peshawar. Pakistan. Journal of Biological Sciences, v.9, n.9, p.1669-1676, 2006. DOI: https://doi.org/10.3923/pjbs.2006.1669.1676 